\title{
Preliminary Evaluation of Some Qualitative Traits of Sugarcane Germplasm of North-Western Nigeria
}

\author{
*1L. Abubakar, ${ }^{2}$ A.A. Aliero, ${ }^{3}$ S.G. Mohammed, ${ }^{2}$ S. Mohammed, ${ }^{1 M}$. Musa and ${ }^{4}$ T.S. Bubuche \\ ${ }^{1}$ Department of Crop Science, Usmanu Danfodiyo University, P.M.B. 2346, Sokoto, Nigeria. \\ 2Department of Biological Sciences, Usmanu Danfodiyo University, P.M.B. 2346, Sokoto, Nigeria. \\ ${ }^{3}$ Department of Agronomy, Bayero University Kano, Nigeria. \\ ${ }^{4}$ Department of Agric Education, Adamu Augie College of Education, Argungu, Kebbi State, Nigeria. \\ [Corresponding author: Email; dr.lawaliabubakar@yahoo.com; 梁: +2348039657021]
}

\begin{abstract}
Thirty five local sugarcane (Saccharum spp.) accessions were collected in an expedition in NorthWestern Nigeria, covering Sokoto, Kebbi, Zamfara, Katsina, Kaduna, Kano and Jigawa States in September 2011. The germplasm accessions were maintained at Usmanu Danfodiyo University Sokoto. Data on leaf colour, leaf sheath colour, thrashability, ligular process, spines (pubescence), stem colour and bud groove were collected. The study indicate that shape of the accessions could be used either directly or indirectly as a selection tool for pest resistance and mechanical cultivation in sugarcane. Leaf sheath colour and number of green leaves per plant could form additional selection tools for high photosynthesis efficiency to the already existing ones.

Key words: Evaluation, Sugarcane, Germplasm, Characters, Accessions
\end{abstract}

\section{INTRODUCTION}

Sugarcane is currently grown in over 110 countries in the world (FAOSTAT, 2009). An estimated 989,466,957 tonnes were produced worldwide, harvested from $8,748,983$ hectares in 2009 , with an average of $893,671 \mathrm{~kg} / \mathrm{ha}$. The African total production for the year 2009 was 9,984,154,405 tonnes harvested from 367,488 hectares at a yield per hectare of $59,853 \mathrm{~kg}$ (FAOSTAT, 2009). In Nigeria the total production was 24,661 tonnes, harvested from 35,324 hectares at an average yield of $90,405 \mathrm{~kg} / \mathrm{ha}$ (FAOSTAT, 2009).

Sugarcane (Saccharum officinarum L.) is an important industrial cash crop in Nigeria (Olaoye, 2006). Besides sugar production, sugarcane produces numerous valuable byproducts like ethanol used by pharmaceutical industry and used as fuel (Zafar et al., 2009). Also, Noosheen and Ashraf (2001), reported that characters most influenced by environment are quantitative characters such as size and colour e.t.c. Those quantitative characters have less value in cane yield identification than the stable characters (qualitative characters) such as shape of vegetative organs (bud groove, spines, ligules, node-shape and thrashability).

Producing sugarcane seedlings from geneticallydiverse parents or breeding clones is essential for developing high yielding, disease and insect resistant sugarcane cultivars for commercial planting by the sugar industry or by local cane chewing farmers (Olaoye, 2005). Land races of cultivated crops are believed to be useful donors of favourable alleles for adaptation (Olaoye, 2006). Also, wild progenitors of sugarcane have been reported to act as donors of variable agronomic characters and thus play crucial role in the development of modern commercial varieties (Dunckelman and Breaux, 1969). Higher cane yield is the function of higher genetic potential of a variety (Maqbool et al., 2001). Thus, efforts are made to increase cane production by introducing high yielding varieties and adoption of improved crop production techniques (Farooq, 1989). Traits such as biomass and sugar yield are met by different progeny testing stages before the choice of the best progeny clones is suggested for preliminary or advanced yield trials (Gill, 1999). Among environmental factors that have impact on sugarcane breeding are temperature (Bull and Glasziou, 1963), rainfall distribution (Olaoye, 2006), photoperiod, rising atmospheric concentrations of $\mathrm{CO}_{2}$ (Ehara and Takamura, 1994) and pollution levels. For example, intermittent occurences of night temperature below $18^{\circ} \mathrm{C}$, during the period of floral induction reduce flowering intensity and/or delay seedling emergence (Dunckelman and Breaux, 1969). While frequent occurrences of day- time temperatures exceeding $31^{\circ} \mathrm{C}$ acting singly or in combination with moisture stress, have also been implicated in similar reduction in flowering intensity or delayed emergence (Olaoye, 2006). Harsh weather conditions also result in pollen 
Nigerian Journal of Basic and Applied Science (June, 2013), 21(2): 116-211

abortion or permanent pollen shed, which limit cross manipulation by breeders during the crossing period. Furthermore, amount and distribution of rainfall during flowering do affect pollen viability and seed set in sugarcane (Olaoye, 2006).

The objective of the study was to evaluate some qualitative characters that are related to yield and quality of sugarcane germplasm of North-western Nigeria.

\section{MATERIALS AND METHODS}

Thirty five local sugarcane accessions were collected in an expedition in North-western Nigeria, covering Sokoto, Kebbi, Zamfara, Katsina, Kaduna, Kano and Jigawa States in September 2011 (Table 1). They were planted at Usmanu Danfodiyo University, sokoto immediately. Sokoto is located in the Sudan Savanna agro-ecological zone of Nigeria on latitude $13^{\circ} 01^{\prime} \mathrm{N}$; longitude $5^{0} 15^{\prime} \mathrm{E}$ altitude of about $350 \mathrm{~m}$ above sea level (ASL). Mean annual rainfall is about $752 \mathrm{~mm}$, the minimum and maximum temperatures are $26^{\circ}$ and $35^{\circ}$, respectively, and relative humidity of $23-41 \%$. The area is characterized by long dry season with cool air during Hamattan (November - February), dry air during hot season from March - May followed by a short rainy season (Bello, 2006).

Data on stalk and leaf quality characters were observed and recorded from the accessions. These included joint/node-shape, ligular process, stem colour, bud groove, leaf sheath colour, leaf colour, presence or absence of spines and thrashability based on morphological description of Artschwager (1948) and Van Diller wijin (1952).

\section{RESULTS}

Results obtained indicate that more than half of the accessions had stem and leave sheath with green/purple colour. Those with straight node were more than those with staggered nodes (ZM/11/01, ZM/11/03, SOK/11/04, KT/11/01, KN/11/04) (Table 2). Those with bud groove were few (KN/11/03, ZM/11/01, $\mathrm{ZM} / 11 / 02, \mathrm{KN} / 11 / 04$ ) and all of the accessions had loose thrashability except three (JG/11/01, ZM/11/07, $\mathrm{KB} / 11 / 03$ ) that have tight thrashability. While those with green leaves were also greater in number(30 accessions) than those with yellow/green (KT/11/03, $\mathrm{KD} / 11 / 01, \mathrm{~KB} / 11 / 06, \mathrm{KN} / 11 / 01, \mathrm{KN} / 11 / 04$ ), and those with spines on their leaves were more numerous than those that had no spines (KD/11/03, KD/11/02, $\mathrm{KB} / 11 / 04, \mathrm{KN} / 11 / 04$ ).

\section{DISCUSSION}

Observations on the accessions indicate that the quantum of variability in the accessions with respect to stalk shape showed that only very few accessions had staggered nodes (five accessions), while most of them had straight nodes, which is a very important character for mechanized farming in sugarcane (Farooq 1989). Straight cane stalk, and small blade joint are the quality characters that make sugarcane varieties the most suitable for mechanical cultivation and post harvest handling (Faroog 1989). It was also reported by Piscitelli (1994), that the most important exomorphological characters of sugarcane variety were the shape of the aerial organs, because it is a qualitative character that is not influenced by environmental factors thus; can be used as a selection tool in any breeding programme. Most of the accessions had green leaves which are very important trait that play vital role in photosynthesis. However, Olaoye (2005) reported that leaf colour had a negative association with stalk length. Most of the accessions also had spines on their leaves. Leaf spines is among different control measures used by host plant resistance (HPR), which is of paramount importance as the approach does not poss any adverse effect on nontarget organisms (Dhaliwal and Arora 2004). The accessions also had high thrashability that plays a vital role in storage of sucrose for long time after senescence period in sugarcane (Dariew and Kultiasova, 1981).

\section{CONCLUSION}

The preliminary evaluation of sugarcane germplasm collected indicate that diversity exist among the accessions under study with respect to potentiality for mechanical cultivation and source of genes for resistance to pests.

\section{ACKNOWLEDGEMENTS}

We wish to acknowledge the Agricultural Research Council of Nigeria (ARCN), Abuja, Nigeria for funding the research. 
Table1: Thirty five accessions collected in expedition from North-Western Nigeria.

\begin{tabular}{|c|c|c|}
\hline $\mathrm{S} / \mathrm{N}$ & Accessions & Descriptions \\
\hline & Sokoto State & \\
\hline 1 & Sok/11/01 & Cultivated under irrigation less than one year under rain fed \\
\hline 2 & Sok/11/02 & White in colour, fast growth and disease resistance \\
\hline \multirow[t]{2}{*}{3} & Sok/111/03 & White, disease resistance under high moisture condition and six months with irrigation \\
\hline & Kebbi State & \\
\hline 4 & $\mathrm{~Kb} / 11 / 01$ & White disease resistance and six months under good management \\
\hline 5 & $\mathrm{~Kb} / 11 / 02$ & Less popular but sweeter than kebbi five \\
\hline 6 & $\mathrm{~Kb} / 11 / 03$ & $-\quad-\quad-$ \\
\hline 7 & $\mathrm{~Kb} / 11 / 04$ & Yar Bacita, White and susceptible to stem borer \\
\hline 8 & $\mathrm{~Kb} / 11 / 05$ & White, and susceptible to many pest. \\
\hline 9 & $\mathrm{~Kb} / 11 / 06$ & White, five months under good management, less tillers \\
\hline \multirow[t]{2}{*}{10} & $\mathrm{~Kb} / 11 / 07$ & White, Yar tsauri, can be grown any where and sweeter than kebbi 6 . \\
\hline & Zamfara State & \\
\hline \multirow[t]{2}{*}{11} & $\mathrm{Zm} / 11 / 01$ & White, high tillers, grow better at fadama area. \\
\hline & $\mathrm{Zm} / 11 / 02$ & White, most popular, third indigenous in the area. \\
\hline 12 & $\mathrm{Zm} / 11 / 03$ & White, called kantoma,second indegenours. \\
\hline 13 & $\mathrm{Zm} / 11 / 04$ & White, called bahausa less popular but use medicinally for eye treatment. \\
\hline 14 & $\mathrm{Zm} / 11 / 05$ & White, called Yar kudus, cultivated over 40 years in the area. \\
\hline 15 & $\mathrm{Zm} / 11 / 06$ & White, called bahausa high response to fertilizer, need no irrigation when established \\
\hline 16 & $\mathrm{Zm} / 11 / 07$ & White, called kwandaji, has high tillering ability 50-100 tillers/stool \\
\hline 17 & $\mathrm{Zm} / 11 / 08$ & White,called kwandaji,its planting time is NOV-DEC. response very well to fertilizer. \\
\hline 18 & Katsina State & \\
\hline 19 & $\mathrm{KT} / 11 / 01$ & White, called kwandaji, use medicinaly for liver disease treatment \\
\hline 20 & $\mathrm{KT} / 11 / 02$ & White, early maturity but difficult to chew during dry season. \\
\hline 21 & $\mathrm{KT} / 11 / 03$ & White. \\
\hline 22 & $\mathrm{KT} / 11 / 04$ & $\begin{array}{l}\text { White, called kyalla sweeter than any variety sarrobund,10mtks.susceptible to disease } \\
\text { and pest }\end{array}$ \\
\hline \multirow[t]{2}{*}{23} & $\mathrm{KT} / 11 / 05$ & White, response to fertilizer application \\
\hline & Kaduna State & \\
\hline 24 & $\mathrm{KD} / 11 / 01$ & White, less popular. \\
\hline 25 & $\mathrm{KD} / 11 / 02$ & White, sweet, soft, and less marbketable. \\
\hline 26 & $\mathrm{KD} / 11 / 03$ & White called kwandaij difficult to chew but drought tolerant \\
\hline \multirow[t]{2}{*}{27} & $\mathrm{KD} / 11 / 04$ & White, called kwandaji, shorter and resistance to water logging \\
\hline & Kano State & \\
\hline 28 & $\mathrm{KN} / 11 / 01$ & White, called kantoma, 10months duration,and resistance to disease. \\
\hline 29 & $\mathrm{KN} / 11 / 02$ & White, called bakarkwandaga and not withstand drought. \\
\hline 30 & $\mathrm{KN} / 11 / 03$ & White, susceptible to pest and disease. \\
\hline \multirow[t]{2}{*}{31} & $\mathrm{KN} / 11 / 04$ & White, easy to chew. \\
\hline & Jigawa State & \\
\hline 32 & $\mathrm{JG} / 11 / 01$ & White, called savannah, 4months duration. \\
\hline 33 & $\mathrm{JG} / 11 / 02$ & White, called gwado-gwado, resistance to disease. \\
\hline 34 & $\mathrm{JG} / 11 / 03$ & White, called gwado-gwado, resistance to disease \\
\hline 35 & $\mathrm{JG} / 11 / 04$ & White, called savannah, 4months duration, soft but less sweeter. \\
\hline
\end{tabular}


Nigerian Journal of Basic and Applied Science (June, 2013), 21(2): 116-211

Table 2: Quality Traits of Sugarcane Accessions from North-Western Nigeria

\begin{tabular}{|c|c|c|c|c|c|c|c|c|}
\hline \multirow[b]{2}{*}{ ACCESSIONS } & \multicolumn{8}{|c|}{ CHARACTERS } \\
\hline & 怘 흥 & 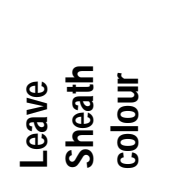 & 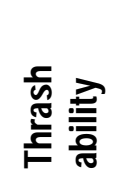 & 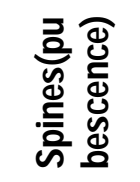 & 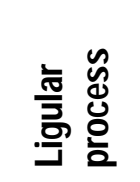 & 흐르응 & 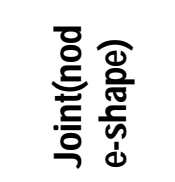 & 을 옹 \\
\hline \multicolumn{9}{|l|}{ Sokoto State } \\
\hline Sok/11/01 & Green & $\begin{array}{l}\text { Green with } \\
\text { purple tinge }\end{array}$ & Loose & Present & Present & $\begin{array}{l}\text { Green with } \\
\text { purple tinge }\end{array}$ & Straight & Absent \\
\hline Sok/11/02 & Green & $\begin{array}{l}\text { Green with } \\
\text { purple tinge }\end{array}$ & Loose & Present & Absent & $\begin{array}{l}\text { Yellow with } \\
\text { purple tinge }\end{array}$ & Straight & Present \\
\hline Sok/11/03 & Green & $\begin{array}{l}\text { Green with } \\
\text { purple tinge }\end{array}$ & Loose & Present & Absent & $\begin{array}{l}\text { Yellow with } \\
\text { Green tinge }\end{array}$ & Straight & Absent \\
\hline Sok/11/04 & Green & $\begin{array}{l}\text { Green with } \\
\text { purple tinge }\end{array}$ & Loose & Present & Present & $\begin{array}{l}\text { Yellow with } \\
\text { Green tinge }\end{array}$ & Straight & Absent \\
\hline \multicolumn{9}{|l|}{ Kebbi State } \\
\hline $\mathrm{Kb} / 11 / 01$ & Green & $\begin{array}{l}\text { Green with } \\
\text { purple tinge }\end{array}$ & Loose & Present & Present & $\begin{array}{l}\text { Green with } \\
\text { purple tinge }\end{array}$ & Straight & Absent \\
\hline $\mathrm{Kb} / 11 / 02$ & Green & $\begin{array}{l}\text { Green with } \\
\text { purple tinge }\end{array}$ & Loose & Present & Absent & $\begin{array}{l}\text { Yellow with } \\
\text { purple tinge }\end{array}$ & Straight & Present \\
\hline $\mathrm{Kb} / 11 / 03$ & $\begin{array}{l}\text { Yellow/ } \\
\text { Green }\end{array}$ & $\begin{array}{l}\text { Green with } \\
\text { purple tinge }\end{array}$ & Tight & Present & Absent & $\begin{array}{l}\text { Yellow with } \\
\text { Green tinge }\end{array}$ & Straight & Absent \\
\hline $\mathrm{Kb} / 11 / 04$ & Green & $\begin{array}{l}\text { Green with } \\
\text { purple tinge }\end{array}$ & Loose & Absent & Present & $\begin{array}{l}\text { Yellow with } \\
\text { Green tinge }\end{array}$ & Straight & Absent \\
\hline $\mathrm{Kb} / 11 / 05$ & Green & $\begin{array}{l}\text { Green with } \\
\text { purple tinge }\end{array}$ & Loose & Present & Present & $\begin{array}{l}\text { Green with } \\
\text { purple tinge }\end{array}$ & Straight & Absent \\
\hline $\mathrm{Kb} / 11 / 06$ & $\begin{array}{l}\text { Yellow/ } \\
\text { Green }\end{array}$ & $\begin{array}{l}\text { Green with } \\
\text { purple tinge }\end{array}$ & Loose & Present & Absent & $\begin{array}{l}\text { Yellow with } \\
\text { purple tinge }\end{array}$ & Straight & Present \\
\hline $\mathrm{Kb} / 11 / 07$ & Green & $\begin{array}{l}\text { Green with } \\
\text { purple tinge }\end{array}$ & Loose & Present & Absent & $\begin{array}{l}\text { Yellow with } \\
\text { Green tinge }\end{array}$ & Straight & Absent \\
\hline \multicolumn{9}{|l|}{ Zamfara State } \\
\hline ZM/11/01 & Green & $\begin{array}{l}\text { Green with } \\
\text { purple tinge }\end{array}$ & Loose & Present & Present & $\begin{array}{l}\text { Green with } \\
\text { purple tinge }\end{array}$ & Staggered & Present \\
\hline $\mathrm{ZM} / 1 / 02$ & Green & $\begin{array}{l}\text { Green with } \\
\text { purple tinge }\end{array}$ & Loose & Present & Absent & $\begin{array}{l}\text { Yellow with } \\
\text { purple tinge }\end{array}$ & Straight & Present \\
\hline ZM/11/03 & Green & $\begin{array}{l}\text { Green with } \\
\text { purple tinge }\end{array}$ & Loose & Present & Absent & $\begin{array}{l}\text { Yellow with } \\
\text { Green tinge }\end{array}$ & Staggered & Absent \\
\hline ZM/11/04 & Green & $\begin{array}{l}\text { Green with } \\
\text { purple tinge }\end{array}$ & Loose & Present & Present & $\begin{array}{l}\text { Yellow with } \\
\text { Green tinge }\end{array}$ & Straight & Absent \\
\hline ZM/11/05 & Green & $\begin{array}{l}\text { Green with } \\
\text { purple tinge }\end{array}$ & Loose & Present & Present & $\begin{array}{l}\text { Green with } \\
\text { purple tinge }\end{array}$ & Straight & Absent \\
\hline ZM/11/06 & Green & $\begin{array}{l}\text { Green with } \\
\text { purple tinge }\end{array}$ & Loose & Present & Absent & $\begin{array}{l}\text { Yellow with } \\
\text { purple tinge }\end{array}$ & Straight & Absent \\
\hline ZM/11/07 & Green & $\begin{array}{l}\text { Green with } \\
\text { purple tinge }\end{array}$ & Tight & Present & Absent & $\begin{array}{l}\text { Yellow with } \\
\text { purple tinge }\end{array}$ & Straight & Absent \\
\hline ZM/11/08 & Green & $\begin{array}{l}\text { Green with } \\
\text { purple tinge }\end{array}$ & Loose & Present & Present & $\begin{array}{l}\text { Yellow with } \\
\text { purple tinge }\end{array}$ & Straight & Absent \\
\hline
\end{tabular}




\begin{tabular}{|c|c|c|c|c|c|c|c|c|}
\hline \multirow[b]{2}{*}{ ACCESSIONS } & \multicolumn{7}{|c|}{ CHARACTERS } & \multirow[b]{2}{*}{ 을 옹 } \\
\hline & 突 흥 & 壳 壳 & 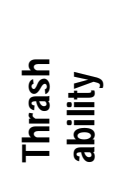 & 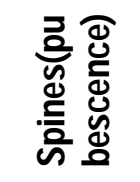 & $\begin{array}{l}\text { 해 } \\
\text { 을 } \\
\text { 을 }\end{array}$ & 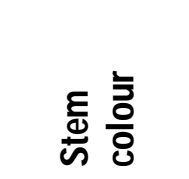 & 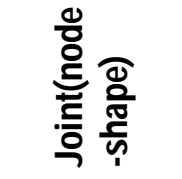 & \\
\hline \multicolumn{9}{|l|}{ Katsina State } \\
\hline $\mathrm{KT} / 11 / 01$ & Green & $\begin{array}{l}\text { Green with } \\
\text { purple tinge }\end{array}$ & Loose & Present & Present & $\begin{array}{l}\text { Green with } \\
\text { purple tinge }\end{array}$ & Staggered & Absent \\
\hline $\mathrm{KT} / 11 / 02$ & Green & $\begin{array}{l}\text { Green with } \\
\text { purple tinge }\end{array}$ & Loose & Present & Absent & $\begin{array}{l}\text { Yellow with } \\
\text { purple tinge }\end{array}$ & Straight & Absent \\
\hline $\mathrm{KT} / 11 / 03$ & $\begin{array}{l}\text { Yellow/ } \\
\text { Green }\end{array}$ & $\begin{array}{l}\text { Green with } \\
\text { purple tinge }\end{array}$ & Loose & Present & Absent & $\begin{array}{l}\text { Yellow with } \\
\text { Green tinge }\end{array}$ & Straight & Absent \\
\hline $\mathrm{KT} / 11 / 04$ & Green & $\begin{array}{l}\text { Green with } \\
\text { purple tinge }\end{array}$ & Loose & Present & Present & $\begin{array}{l}\text { Yellow with } \\
\text { Green tinge }\end{array}$ & Straight & Absent \\
\hline \multicolumn{9}{|l|}{ Kaduna State } \\
\hline $\mathrm{KD} / 11 / 01$ & $\begin{array}{l}\text { Yellow/ } \\
\text { Green }\end{array}$ & $\begin{array}{l}\text { Green with } \\
\text { purple tinge }\end{array}$ & Loose & Present & Present & $\begin{array}{l}\text { Green with } \\
\text { purple tinge }\end{array}$ & Staggered & Absent \\
\hline $\mathrm{KD} / 11 / 02$ & Green & $\begin{array}{l}\text { Green with } \\
\text { purple tinge }\end{array}$ & Loose & Absent & Absent & $\begin{array}{l}\text { Yellow with } \\
\text { purple tinge }\end{array}$ & Straight & Absent \\
\hline KD/11/03 & Green & $\begin{array}{l}\text { Green with } \\
\text { purple tinge }\end{array}$ & Loose & Present & Present & $\begin{array}{l}\text { Yellow with } \\
\text { Green tinge }\end{array}$ & Staggered & Absent \\
\hline $\mathrm{KD} / 11 / 04$ & Green & $\begin{array}{l}\text { Green with } \\
\text { purple tinge }\end{array}$ & Loose & Absent & Absent & $\begin{array}{l}\text { Yellow with } \\
\text { Green tinge }\end{array}$ & Straight & Present \\
\hline \multicolumn{9}{|l|}{ Kano State } \\
\hline $\mathrm{KN} / 11 / 01$ & $\begin{array}{l}\text { Yellow/ } \\
\text { Green }\end{array}$ & $\begin{array}{l}\text { Green with } \\
\text { purple tinge }\end{array}$ & Loose & Present & Present & $\begin{array}{l}\text { Green with } \\
\text { purple tinge }\end{array}$ & Straight & Absent \\
\hline $\mathrm{KN} / 11 / 02$ & Green & $\begin{array}{l}\text { Green with } \\
\text { purple tinge }\end{array}$ & Loose & Present & Absent & $\begin{array}{l}\text { Yellow with } \\
\text { purple tinge }\end{array}$ & Straight & Absent \\
\hline $\mathrm{KN} / 11 / 03$ & Green & $\begin{array}{l}\text { Green with } \\
\text { purple tinge }\end{array}$ & Loose & Present & Absent & $\begin{array}{l}\text { Yellow with } \\
\text { Green tinge }\end{array}$ & Straight & Present \\
\hline $\mathrm{KN} / 11 / 04$ & $\begin{array}{l}\text { Yellow/ } \\
\text { Green }\end{array}$ & $\begin{array}{l}\text { Green with } \\
\text { purple tinge }\end{array}$ & Loose & Absent & Present & $\begin{array}{l}\text { Yellow with } \\
\text { Green tinge }\end{array}$ & Staggered & Present \\
\hline \multicolumn{9}{|l|}{ Jigawa State } \\
\hline$J G / 11 / 01$ & Green & $\begin{array}{l}\text { Green with } \\
\text { purple tinge }\end{array}$ & Tight & Present & Present & $\begin{array}{l}\text { Green with } \\
\text { purple tinge }\end{array}$ & Staggered & Absent \\
\hline$J G / 11 / 02$ & Green & $\begin{array}{l}\text { Green with } \\
\text { purple tinge }\end{array}$ & Loose & Present & Absent & $\begin{array}{l}\text { Yellow with } \\
\text { purple tinge }\end{array}$ & Straight & Absent \\
\hline $\mathrm{JG} / 11 / 03$ & Green & $\begin{array}{l}\text { Green with } \\
\text { purple tinge }\end{array}$ & Loose & Present & Absent & $\begin{array}{l}\text { Yellow with } \\
\text { Green tinge }\end{array}$ & Staggered & Absent \\
\hline$J G / 11 / 04$ & Green & $\begin{array}{l}\text { Green with } \\
\text { purple tinge }\end{array}$ & Loose & Present & Present & $\begin{array}{l}\text { Yellow with } \\
\text { Green tinge }\end{array}$ & Straight & Absent \\
\hline
\end{tabular}

\section{REFERENCES}

Artschwager, E. (1948). Vegetative characters of some wild forms of Saccharum and related grass. U.S. Dept. Agric. Tech. Bull. Pp 51-69pp

Bello, M.S. (2006). Effect of spacing and Potassium on growth and yield of sweet Potato (Ipomoea batatas Lam) in the Sudan savanna of Nigeria.
Unpublished M. Sc. thesis Submitted to the Department of Crop Science, Usmanu Danfodiyo University Sokoto.85p.

Bull, T. A. and Glasziou, K.T. (1963). The evolutionary significance of sugar accumulation in Saccharum. Australian Journal of Biological Sciences, 16: 737742. 
Dhaliwal, G.S. and Arora, R. (2004). Integrated pest management- concepts and approaches, Kalyani Publishers, New Delhi, pp.127-136.

Dariew, A.S. and Kultiasova, E.B. (1981). Leaf structure characters in cotton which condition is resistant to Tetranychus urticae and Aphis gossypii, Botaniecheskii Zhurnal, 66:1250-1209.

Dunckelman P.H. and Breaux, R.D. (1969). Agronomic characteristics of Saccharum pontaneun clones in culture at Houma Lousiana. International Sugarcane Journal, 85(1): 333 -334.

FAOSTAT Data (2009). Food and Agriculture Organization of the United Nations Year book, Vol.51 85p

Ehara, H. and Takamura, T.Y. (1994). Growth and Dry Matter Production of Sugarcane in Warm temperate Zone of Japan. 4. Japanese Journal of Tropical Agriculture, 38: 335-342.

Farooq, M. (1989). Morphological and agricultural characteristics of sugarcane in relation to mechanized agriculture at NARC Islamabad, Portu Rico journal, pp.51-61

Gill, M.B. (1999). High density planting as an economic production strategy Overview and potential benefits. Proc. Australian Society of Sugarcane Technologists, 22: 104- 112.

Grassl, C.O. (1956). The morphology of the grass spikelet with special reference to Saccharum.
Proceedings of International Sugarcane Technology, 9:764-780.

Maqbool, A., Nosheen, N.E. and Ashraf, M. (2001). Morphological Characters of Some Exotic Sugarcane Varieties. Pakistan Journal of Biological Sciences, 4: 471-476.

Nosheen, N.E. and Ashraf, M. (2001). Comparative study of morphological characters of six sugarcane varieties. Department of Biological Science, Azan University of Islamabad Pakistan 48-54pp.

Olaoye, G. (2005). Estimate of ratooning ability in sugarcane under conditions of low available soil moisture in a savanna ecology of Nigeria, Moor Journal of Agricultural Research, 6 (1):16-23

Olaoye, G. (2006). Yield potential of non-irrigated sugarcane germplasm accessions in Savanna ecology of Nigeria, Moor Journal of Agricultural Research, 7(2): 69-75

Piscitelli, F.R. (1994). Principals caracteres exomorfologicos de cultures de cana de azucar TUC lindustraly agricos, 7: 49-57.

Van Dillewinjin, C. (1952). Botany of sugarcane, Walth in, MASS, USA. 357Pp

Zafar, M., Umar, M., Chatha, A.A., Grawal, M.A. and Ahmed, F. (2009). Comparative performance of elite sugarcane clones at advance nursery stage for growth, quality and disease response. Pakistan Sugar Journal, 18: 8-12. 